\title{
逆強化学習とファジィ推論に基づく あいまい性を考虑した報酬関数の設計†
}

\author{
加藤 優太 $* 1 \cdot$ 加納 政芳 $* 2 \cdot$ 中村 剛士*3
}

\begin{abstract}
ロボットの行動則を獲得する方法に逆強化学習を用いて報酬関数を設計する方法がある。ここで，状態空間は，次元数 が増えるにつれて指数関数的に大きくなるため, 状態空間の広さに対して, 観測できる状態遷移数の割合は激減する. 部 分的な状態遷移情報からでも報酬関数を設計することは可能であるが, 得られた報酬関数にはあいまい性が存在すること になる，あいまい性を含む報酬関数を用いて学習する場合には，あいまい性を許容可能な報酬関数が必要となる，そこで 本稿では, 逆強化学習で設計された報酬関数のもつあいまい性をファジィ推論によって数值化する手法を提案する. 実験 の結果, 提案手法によって, 危険度や安全度を考慮した行動系列を学習できる可能性が示唆された。
\end{abstract}

キーワード：逆強化学習, ファジィ推論, 報酬関数

\section{1. はじめに}

近年, 強化学習を使用した研究が数多く行われており [1-3], ロボット制御への応用も盛んである [4-6]. 強化学習問題は, 報酬の設計によって学習の可否が変わってくる場合がある。報 酬を設計する手段には，人が経験から設計する方法と逆強化学 習 [7] を使って設計する方法がある。逆強化学習とは最適な行 動系列を所与とし報酬関数を設計する方法である。ロボットの 制御則を強化学習で学習させるとき, 望ましい行動系列が既知 の場合がある. 既知の最適な行動を所与として報酬を設計し, 強化学習で制御則を学習すれば，望ましい学習結果が得られる 可能性がある。ここで, 複雑な計画問題になるにつれて状態空 間は指数関数的に大きくなる，そのため, 状態空間の広さに対 して, 観測できる状態遷移数の割合は激減する。部分的な状態 遷移情報からでも報酬関数を設計することは可能であるが，得 られた報酬関数には不確実性，すなわちあいまい性が存在する ことになる。このように, 従来手法では観測の穴を補うような 報酬設計がされていないため, 未観測の状態に対するあいまい 性を考慮する必要がある。そこで本稿では, 逆強化学習で設計 された報酬関数のもつあいまい性をファジィ推論によって数值 化することを考える.

逆強化学習には，報酬関数を線形計画法で設計するもの [8] や行動軌跡による特徵期待值で設計するもの [9] などがある が，どれもあいまい性は考慮されていない，実環境への応用を 考えると，あいまい性を考慮できる報酬関数は重要といえる.

Reward Function Considering Ambiguity Using Inverse Reinforcement Learning and Fuzzy Reasoning

Yuta KATO, Masayoshi KANOH, and Tsuyoshi NAKAMURA

*1 中京大学 工学研究科

Graduate School of Engineering, Chukyo University

*2 中京大学 工学部

School of Engineering, Chukyo University

*3 中部大学工学部

College of Engineering, Chubu University
そこで, 逆強化学習で得られた報酬関数をファジイ推論によっ てあいまい性を含む報酬関数へと再設計する手法を提案する。 本手法は, 安全度と危険度の 2 種類の報酬関数を, それぞれ のファジィメンバシップ関数に入力し，ファジィルールマッ プ [10] を用いてそれらを統合した出力を得て報酬関数を設計 するものである。本手法を用いることで，観測された状態に対 する報酬值にあいまい性を持たせて周囲に伝播させることで, 未観測状態に対して観測の穴を補うような報酬関数を設計する ことができる。

\section{2. 提案手法}

一般に, 逆強化学習では, 最適な行動系列を与えることに よって, 報酬関数を設計する. しかしながら, ロボットの行動 則の設計などにおいては, 最悪の行動系列, たとえば筐体部が 接触する動作なども考慮にいれなければ, 望ましい学習結果が 得られない場合がある。このような背景から, 安全な行動と危 険な行動を用いて逆強化学習によって報酬関数を設計する手法 が提案されている [11]. 本稿では, 文献 [11] と同様に安全な 行動系列と危険な行動系列を所与として報酬関数を設計するこ とを考える。

提案手法のアルゴリズムは次の通りである.

1. 安全な行動系列による報酬関数の設計： すべての安全な行動系列 $i$ に対して,

(a) 行動系列 $i$ を所与とし, 逆強化学習によって報酬関数 $\boldsymbol{R}_{i}$ を設計する

(b) 状態 $s$ の安全度 $r_{s} \in[0,1]$ を次の式で決定する.

$$
r_{s}=\sum_{i} \sum_{s^{\prime} \in S} \alpha^{d i s\left(s, s^{\prime}\right)} \frac{R_{i}\left(s^{\prime}\right)}{R_{\max }},
$$

ここで, $S$ は $\boldsymbol{R}_{\boldsymbol{i}}$ において報酬が設計されている状態 集合, $\alpha$ はパラメータ, $\operatorname{dis}\left(s, s^{\prime}\right)$ は状態 $s$ と $s^{\prime}$ の距離 を求める関数, $R_{i}\left(s^{\prime}\right)$ は逆強化学習によって状態 $s^{\prime}$ に 設定された報酬值である。 $R_{\max }$ は次式で与えられる.

$$
R_{\max }=\max _{i} \max _{s^{\prime} \in S} R_{i}\left(s^{\prime}\right) .
$$




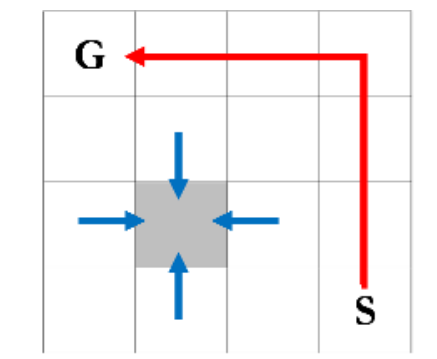

一安全な経路 一危険な経路

図 1 実装例で用いる環境

2. 危険な行動系列による報酬関数の設計：

すべての危険な行動系列 $j$ に対して,

(a) 行動系列 $j$ を所与とし, 逆強化学習によって報酬関数 $\overline{\boldsymbol{R}_{j}}$ を設計する。

(b) 状態 $s$ の危険度 $\overline{r_{s}} \in[0,1]$ を次の式で決定する.

$$
\overline{r_{s}}=\sum_{j} \sum_{s^{\prime} \in \bar{S}} \beta^{d i s\left(s, s^{\prime}\right)} \frac{\overline{R_{j}}\left(s^{\prime}\right)}{\overline{R_{\max }}},
$$

ここで, $\bar{S}$ は $\overline{\boldsymbol{R}_{j}}$ において報酬が設計されている状態 集合, $\beta$ はパラメータ, $\overline{R_{\max }}$ は次式で与えられる.

$$
\overline{R_{\max }}=\max _{j} \max _{s^{\prime} \in \bar{S}} \overline{R_{j}}\left(s^{\prime}\right) .
$$

3. 状態 $s$ に与えられた $r_{s}$ および $r_{s}$ をそれぞれ, 安全度と危 険度のメンバシップ関数へ入力し, メンバシップ值（前件 部）を算出する.

4. 安全度と危険度で構成される 2 次元ファジィルールマッ プ [10]にメンバシップ值を入力し, 各状態 $s$ の報酬值（後 件部) $r(s)$ を得る。

文献 [11] では, 逆強化学習によって得られた安全行動の報 酬関数 $\boldsymbol{R}_{i}$ と危険行動の報酬関数 $\overline{\boldsymbol{R}_{j}}$ を次式のように直接的に 加減算している.

$$
\boldsymbol{R}=\boldsymbol{R}_{i}-\overline{\boldsymbol{R}_{j}}+R_{\text {base }}
$$

この方法では, 入力系列に含まれていない状態，すなわち観測 されていない状態があるときに，観測の穴を補うような報酬 設計ができないという問題がある。一方, 本手法を用いること で，設計者の意図する報酬值を柔軟に表現できるのに加え，未 観測状態に対しても，報酬值にあいまい性を持たせて周囲に伝 播させることで観測の穴を補うような報酬関数を設計すること ができる.

\section{3. 実装例}

本節では，提案手法の実装例を示す。

図 1 に実装例で使用する格子空間環境と逆強化学習に与える 行動系列を示す。同図において, $\mathrm{S}$ は初期状態，Gは目標状態， 灰色のマスは行動不能になるマスを表している.

\section{1 逆強化学習による報酬関数の設計}

逆強化学習は, 最適な行動系列や環境モデルを所与として報 酬関数を求める問題として定義される。実装例では, $\mathrm{Ng}$ の逆

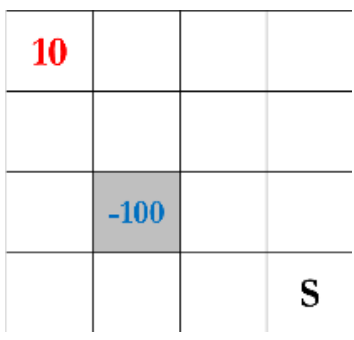

図己 $\mathrm{Ng}$ の逆強化学習によって得られた報酬関数の一例

\begin{tabular}{|c|c|c|c}
\hline 1 & 0.4 & 0.16 & \\
\hline 0.4 & 0.16 & & \\
\hline 0.16 & & & \\
\hline & & & $\mathbf{S}$ \\
\hline
\end{tabular}

安全度

(a)

\begin{tabular}{|l|ll|l|}
\hline & 0.09 & & \\
\hline 0.09 & 0.3 & 0.09 & \\
\hline 0.3 & 1 & 0.3 & 0.09 \\
\hline 0.09 & 0.3 & 0.09 & $\mathbf{S}$ \\
\hline
\end{tabular}

危険度

(b)
図 3 安全度と危険度の報酬関数

強化学習 [8] 使用する.

$\mathrm{Ng}$ の逆強化学習では, 各状態 $s_{i}(i=1,2, \ldots, N)$ における 行動集合 $A$, および行動系列 $a^{*}$ を所与とし, 次式の線形計画 問題を解くことによって報酬関数 $\boldsymbol{R}$ を推定する。

$$
\begin{gathered}
\operatorname{maximize}: \sum_{i=1}^{N} \min _{a \in A \backslash a^{*}}\left\{\left(\boldsymbol{P}_{a^{*}}(i)-\boldsymbol{P}_{a}(i)\right)\left(\boldsymbol{I}-\gamma \boldsymbol{P}_{a^{*}}\right)^{-1} \boldsymbol{R}\right\} \\
-\lambda\|\boldsymbol{R}\|_{1}
\end{gathered}
$$

subject to : $\left(\boldsymbol{P}_{a^{*}}-\boldsymbol{P}_{a}\right)\left(\boldsymbol{I}-\gamma \boldsymbol{P}_{a^{*}}\right)^{-1} \boldsymbol{R} \geq 0$,

$$
\forall a \in A \backslash a^{*}, \quad\left|\boldsymbol{R}_{i}\right| \leq R_{\max }, i=1, \ldots, N .
$$

式 (6)において, 報酬関数 $\boldsymbol{R}$ は列べクトルとして表現され, そ の各要素は状態 $s_{i}$ における報酬 $\boldsymbol{R}_{i}$ で与えられる. 状態遷移行 列 $\boldsymbol{P}_{a}$ は行動 $a$ の状態遷移確率で与えられる $N \times N$ 行列であ り, その各要素 $(i, j)$ は状態 $s_{i}$ において行動 $a$ を実行したとき に $s_{j}$ に遷移する確率で与えられる. $\boldsymbol{P}_{a}(i)$ は $\boldsymbol{P}_{a}$ の第 $i$ 行べク

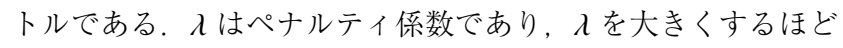
単純な報酬関数が得られる。 I は $N \times N$ の単位行列, $\gamma$ は割引 率, $R_{\max }(>0)$ は報酬の上限である.

図 1 に示す経路を $\mathrm{Ng}$ の逆強化学習に与えた際に, 得られる 報酬関数の一例を図 2 に示す.

\section{2 安全度と危険度の決定}

式 (1)〜(4)によって各状態の安全度と危険度を決定する. 図 3 に算出された安全度と危険度の值を示す。これらの值をメン バシップ関数に入力する.

\section{3 ファジィ推論}

本手法では, メンバシップ関数とファジィルールマップ [10] を用いてあいまい性を数值化する。まず，安全度 $r_{s} \in[0,1]$ お よび危険度 $\overline{r_{s}} \in[0,1]$ をメンバシップ関数に入力する. 図 4 に, 安全度と危険度のメンバシップ関数の実装例を示す. 同図 


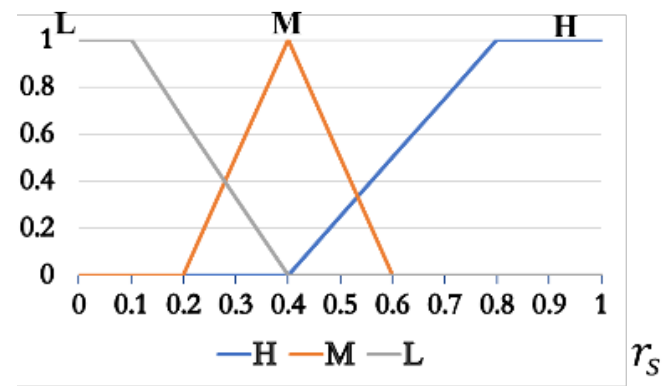

安全度

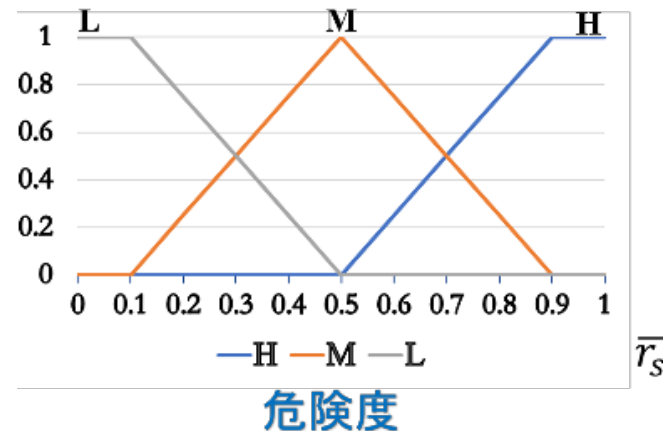

図 4 メンバシップ関数の実装例

\begin{tabular}{|c|c|c|c|}
\hline H & M & $0.75 \mathrm{~L}$ & \\
\hline $\mathrm{M}$ & $0.75 \mathrm{~L}$ & & \\
\hline $0.75 \mathrm{~L}$ & & & \\
\hline & & & $\mathrm{S}$ \\
\hline
\end{tabular}

安全度

(a)

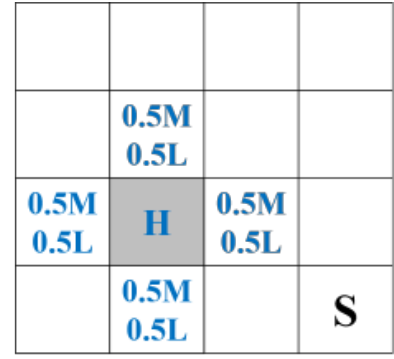

危険度

(b)
図 5 メンバシップ值

において，「H」にいくほど安全度や危険度が高いことを示し， 「L」にいくほど安全度や危険度が低いことを示している，安全 度と危険度をメンバシップ関数に入力して得られたメンバシッ プ值を図 5 に示す。なお，メンバシップ值が 0 のときの表記は 省略している.

各状態は，安全度と危険度の 2 つの性質を持っている。これ らから 1 つの性質, すなわち報酬関数を決定するためにファ ジィルールマップを使用する。図 6(a) にファジィルールマッ プの実装例を, 図 6(b) に得られたメンバシップ值を示す.

最後に，後件部の処理によって報酬值を決定する，実装例で は，後件部にシングルトン [12]を使用する。図 7 に後件部の 実装例を, 図 8 に非ファジィ化に重心法を用いて決定した報酬 值を示す.

単純に安全度と危険度を加算するだけでは, 各状態の持つ安 全度や危険度を正確に表現することができない，本手法を用い ることで，それらを適切に表現できるのに加え，観測されてい ない状態に対しても，あいまい性を持たせて報酬值を決定する ことができる.

\begin{tabular}{c|c|c|c}
$r_{s}$ & $\mathrm{H}$ & $\mathrm{M}$ & $\mathrm{L}$ \\
\hline $\mathrm{H}$ & $\mathrm{RH}$ & $\mathrm{RLL}$ & $\mathrm{RI.L}$ \\
\hline $\mathrm{M}$ & $\mathrm{RH}$ & $\mathrm{RMM}$ & $\mathrm{RLM}$ \\
\hline $\mathrm{I}$. & $\mathrm{RH}$ & $\mathrm{RMH}$ & $\mathrm{RI} . \mathrm{H}$ \\
\hline
\end{tabular}

(a)

\begin{tabular}{|c|c|c|c|}
\hline RH & RMH & 0.75 RLH & RLH \\
\hline RMH & $\begin{array}{c}0.5 \text { RLM } \\
0.5 \text { RLH }\end{array}$ & RLH & RLH \\
\hline $\begin{array}{c}0.5 \text { RLM } \\
0.5 \text { RLH }\end{array}$ & RLL & $\begin{array}{c}0.5 \text { RLM } \\
0.5 \text { RLH }\end{array}$ & RLH \\
\hline RLH & $\begin{array}{c}0.5 \text { RLM } \\
0.5 \text { RLH }\end{array}$ & RLH & RLH \\
\hline
\end{tabular}

(b)
図 6 ファジィルールマップと適合度

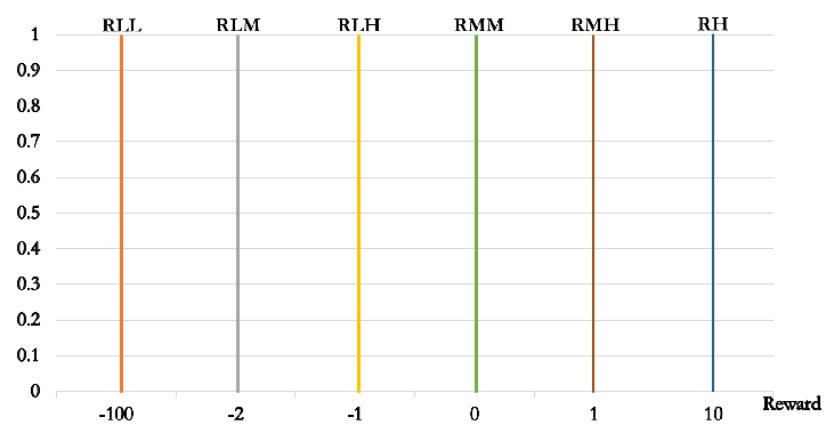

図 7 後件部の実装例

\begin{tabular}{|c|c|c|c|}
\hline 10 & 1 & -1 & -1 \\
\hline 1 & -1.5 & -1 & -1 \\
\hline-1.5 & -100 & -1.5 & -1 \\
\hline-1 & -1.5 & -1 & -1 \\
\hline
\end{tabular}

図 8 実装例での報酬值

\section{4. 実験}

\section{1 実験設定}

実験環境として, 図 9 に示す格子空間のシミュレーション環 境を用いる。同図において，S，G，灰色のマスは，それぞれ初 期状態, 目標状態, 行動不能マスを表している。逆強化学習に は, $\mathrm{Ng}$ の逆強化学習を用いる. $\mathrm{Ng}$ の逆強化学習のパラメータ は, $\gamma=0.8, \lambda=0.5$ とする. 図 10 に $\mathrm{Ng}$ の逆強化学習に与え る行動系列を示す

図 11 および図 12 に, 安全度と危険度のメンバシップ関数 を示す。図 13 にファジィルールマップを示す，後件部は，図 14 に示すシングルトンとし, 各状態の報酬值を決定する。こ れらの設計パラメータは実験的に決定した。非ファジィ化には 重心法を用いる。提案手法のパラメータは， $\alpha=0.3, \beta=0.2$ とする。

得られた報酬関数を用いて学習を行う。実験では，Q学習 を用いる. Q 学習では, 時刻 $t$ における状態 $s_{t}$ において行動 $a_{t}$ を選択した際に, 行動価值関数 $Q\left(s_{t}, a_{t}\right)$ を以下の式で更新 


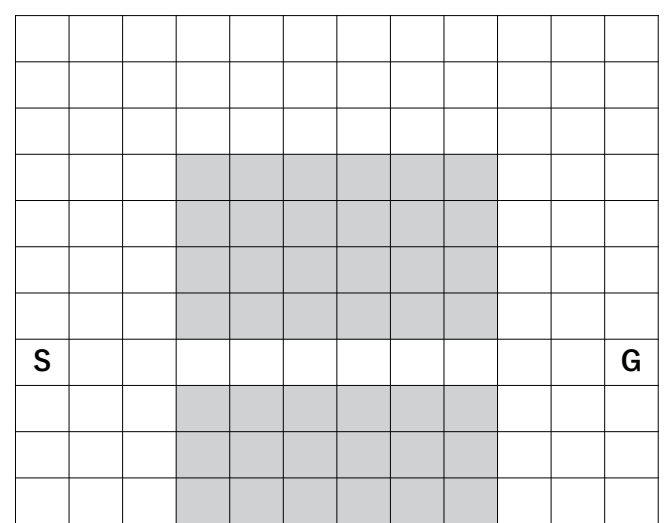

図 9 実験環境

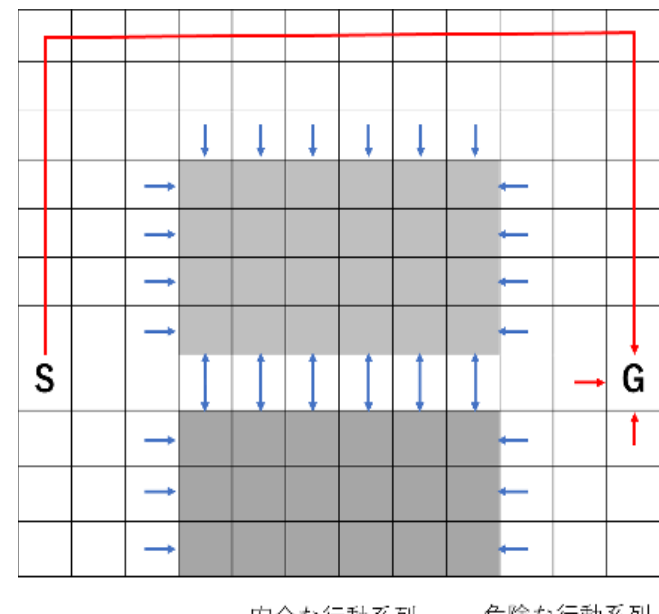

図 10 逆強化学習に与えた行動系列

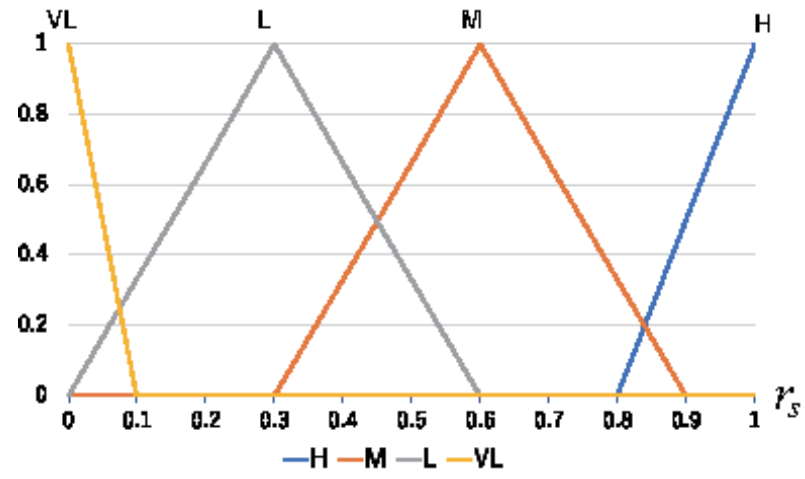

図 11 安全度のメンバシップ関数

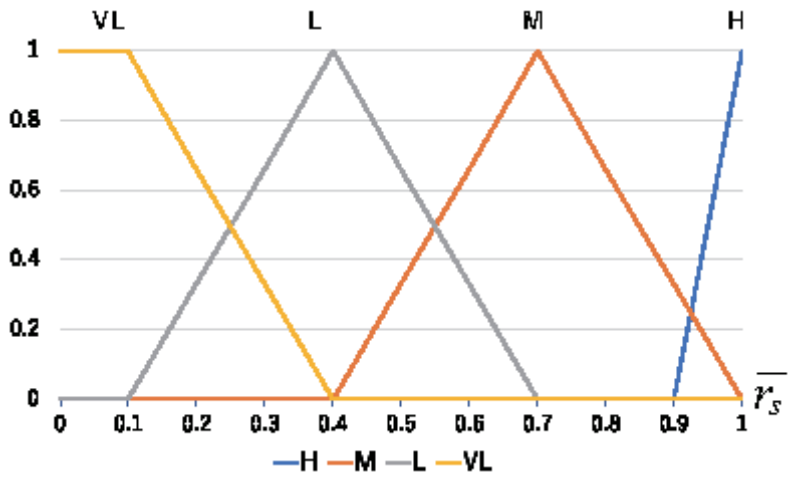

図 12 危険度のメンバシップ関数

\begin{tabular}{|c|c|c|c|c|}
\hline$\widehat{r_{S}} r_{S}$ & $\mathrm{H}$ & $\mathrm{M}$ & $\mathrm{L}$ & $\mathrm{VL}$ \\
\hline $\mathrm{H}$ & $\mathrm{RH}$ & $\mathrm{RLVL}$ & $\mathrm{RLVL}$ & $\mathrm{RLVL}$ \\
\hline $\mathrm{M}$ & $\mathrm{RH}$ & $\mathrm{RL}$ & $\mathrm{RLM}$ & $\mathrm{RLL}$ \\
\hline $\mathrm{L}$ & $\mathrm{RH}$ & $\mathrm{RMH}$ & $\mathrm{RMM}$ & $\mathrm{RML}$ \\
\hline $\mathrm{VL}$ & $\mathrm{RH}$ & $\mathrm{RHM}$ & $\mathrm{RHL}$ & $\mathrm{RHVL}$ \\
\hline
\end{tabular}

図 13 ファジィルールマップ

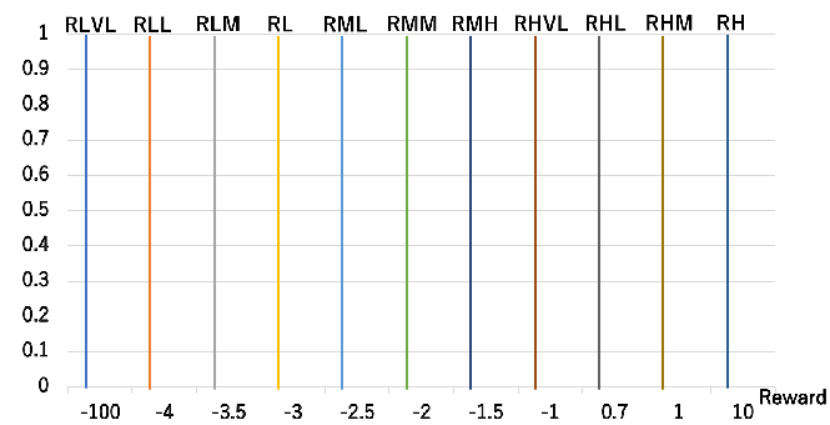

図 14 後件部

する。

$Q\left(s_{t}, a_{t}\right) \leftarrow Q\left(s_{t}, a_{t}\right)+\sigma\left(r_{t+1}+\eta \max _{a} Q\left(s_{t+1}, a\right)-Q\left(s_{t}, a_{t}\right)\right)$,

ここで, $r_{t+1}$ は報酬， $\sigma$ は学習率， $\eta$ は割引率である。実験で は $\sigma=0.1, \eta=0.9$ とする.

\section{2 実験結果}

図 15 に $\mathrm{Ng}$ の逆強化学習によって得られた報酬関数（ただ し移動毎に与えられる報酬 -1 も含まれている) を, 図 16 に 提案手法によって設計された報酬関数を示す。図 17 に, 提案 手法で設計された報酬関数を用いて Q 学習で最適経路を求め た結果を示す。同図より, 提案手法を用いることによって, 与 えた安全な行動系列に類似した経路を学習できていることがわ かる.

図 18 に, Ng の逆強化学習で設計された報酬関数を用いて $\mathrm{Q}$ 学習で最適経路を求めた結果を示す. 同図より, $\mathrm{Ng}$ の逆強 化学習のみでは, 迁回経路を正しく学習できていないことが見 て取れる。図 15 を見るとわかるように, Ngの強化学習によっ て得られた報酬関数では, 行動不能マスと行動不能マスの間の 細い通路を通過するのに伴う危険性が考慮されておらず，最短 経路を学習してしまっている，ロボットを安全に移動させるこ とを考えると行動不能になる可能性の高い経路を迂回すること が望ましい，提案手法では，ファジィ推論によって行動不能マ スの危険度が周囲の状態にも伝播しており，危険な経路を迂回 できるような報酬関数が得られていることがわかる。これによ り，迂回経路を学習していることが確認できる.

以上のことから, 提案手法によって, 危険度や安全度を考慮 した行動系列を学習できる可能性が示唆された. 


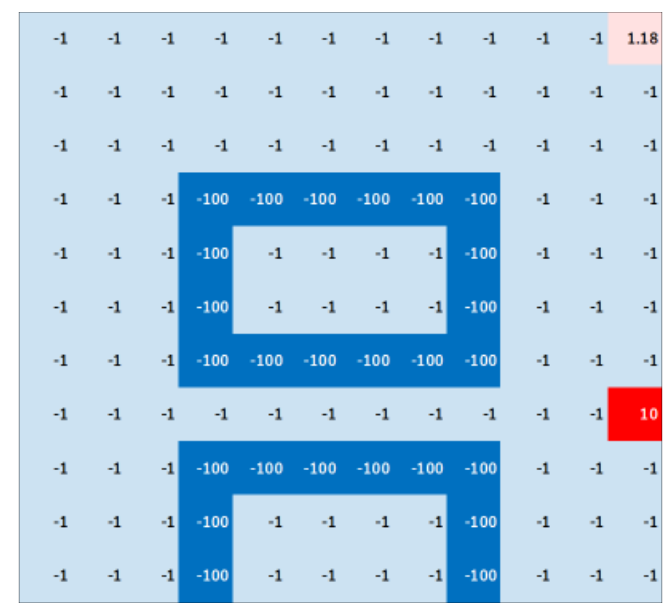

図 $15 \mathrm{Ng}$ の逆強化学習によって得られた報酬関数（ただし 移動毎に与える報酬 -1 も含まれている)

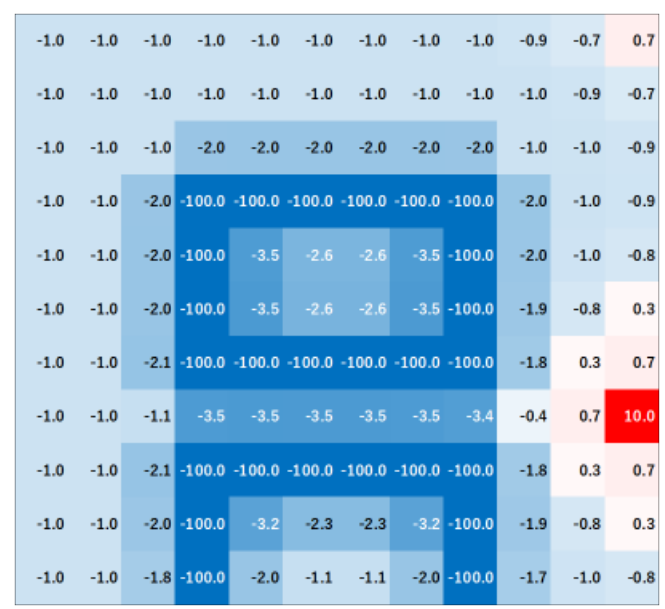

図 16 提案手法によってえられた報酬関数

\section{5. おわりに}

本稿では，逆強化学習とファジィ推論を用いた報酬関数の設 計手法を提案した．提案手法によって設計された報酬関数を用 いて強化学習を行った場合と, 逆強化学習単独で設計された報 酬関数を用いて強化学習を行った場合を比較した結果, 提案手 法を用いることによって, あいまい性を考慮した学習が行える ことが示唆された. また, 本手法のパラメータ $\alpha, \beta$ の決定は, ファジィ推論におけるメンバシップ関数等の設計と比較して, 状態空間の各次元において報酬值をどの程度伝播させるべきか を意識すれば比較的容易にできると考える，加えて，本手法に よって報酬值が伝播させることによって学習効率が向上する可 能性もある。しかしその一方で, 本手法のメンバシップ值の決 定に必要となる計算量は, 状態空間の次元数に応じて指数関数 的に増加する．本手法を用いることによって報酬関数にあいま い性を持たせ，強化学習にかかる計算量を軽減することも期待 されるが, 報酬関数の設計に時間を要するという矛盾した問題 をかかえている，今後は，メンバシップ值の決定にかかる計算 量のオーダーを軽減する手法を検討しつつ，様々な環境下で実 験を行い，本手法の有効性を確認する。

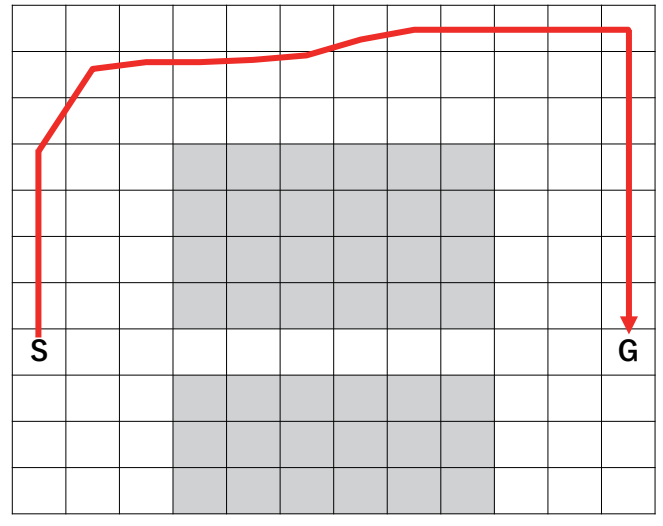

図 17 提案手法の学習経路 (20 回平均)

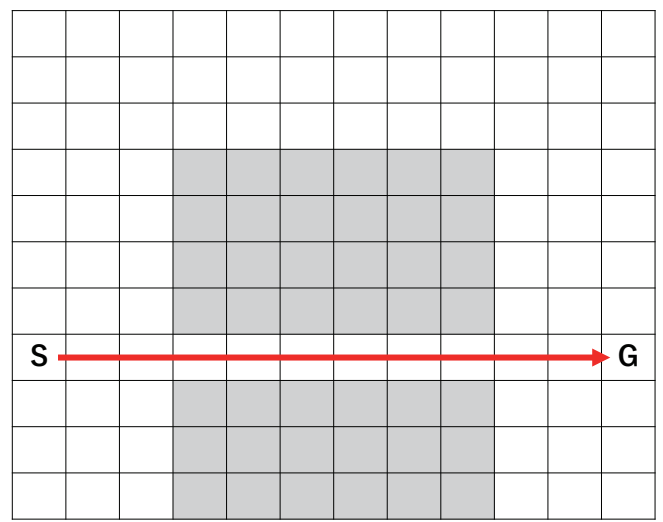

図 18 比較手法の学習経路 (20 回平均)

\section{参 考 文 献}

[1] Y.Zhu, T. Hayashi, and Y. Ohsawa: "Gradient Descent Optimization by Reinforcement Learning," Proc. of the Annual Conf. of the Japanese Society for Artificial Intelligence, Jun. 4-7, Niigata, 2H4-E-2-04, 2019.

[2] Y. Chandak, G. Theocharous, J. Kostas, S. Jordan, and P. S. Thomas: "Learning Action Representations for Reinforcement Learning," Proc. of the 36th Int. Conf. on Machine Learning, Jun. 9-15, Long Beach, Vol.97, pp. 941-950, 2019.

[3] S. Li, Y. Wu, X. Cui, H. Dong, F. Fang, and S. Russell: "Robust Multi-Agent Reinforcement Learning via Minimax Deep Deterministic Policy Gradient," Proc. of the AAAI Conf. on Artificial Intelligence, Jan. 27-Feb. 1, Honolulu, pp. 4213-4220, 2019.

[4] I. Ichikawa and T. Ushio: "Application of Reinforcement Learning to Adaptive Control of Connected Vehicles," Nonlinear Theory and Its Applications, IEICE, Vol.10, No.4, pp. 443-454, 2019.

[5] S. Spielberg, A. Tulsyan, N. P. Lawrence, P. D. Loewen, and R. B. Gopaluni: "Toward Self-Driving Processes: A Deep Reinforcement Learning Approach to Control," AIChE J., Vol.65, No.6, 2019.

[6] A. E. Sallab, M. Abdou, E. Perot, and S. Yogamani: "Deep Reinforcement Learning Framework for Autonomous Driving," IS\&T Electronic Imaging, Autonomous Vehicles and Machines, pp. 70-76, 2017.

[7] S. Russell: "Learning Agents for Uncertain Environments, Proc. of the 11th Annual Conf. on Computational Learning Theory, Jul. 24-26, Wisconsin, pp. 101-103, 1998.

[8] A. Y. Ng and S. J. Russell: "Algorithms for Inverse Reinforcement Learning," Proc. of the 17th Int. Conf. on Machine Learning, Jun. 29-Jul. 2, San Francisco, pp. 663-670, 2000.

[9] P. Abbeel and A. Y. Ng: “Apprenticeship Learning via Inverse 
Reinforcement Learning," Proc. of the 21st Int. Conf. on Machine Learning, Jul. 4-8, Banff, 2004.

[10] 前田陽一郎: “顕著性マップに基づく全方向車椅子の視線教示 システムに扔ける人間の目標指示についての行動意図推定, 知 能と情報, Vol.30, No.5, pp. 717-724, 2018.

[11] 加藤優太, 加納政芳: “逆強化学習のための安全度を考慮した報 酬関数の基礎的検討, 第 46 回東海ファジイ研究会, 2 月 17-18 日, 南知多, P1-03, 2019.

[12] T. Takagi and M. Sugeno: "Fuzzy Identification of Systems and its Applications to Modeling and Control, IEEE Trans. on Systems, Man, Cybernetics, Vol.15, No.1, pp. 116-132, 1985.

(2021 年 5 月 17 日 受付)

(2021 年 6 月 4 日 採録)

[問い合わせ先]

干466-8666 愛知県名古屋市昭和区八事本町 101-2

中京大学 工学部

加納 政芳

E-mail: mkanoh@sist.chukyo-u.ac.jp

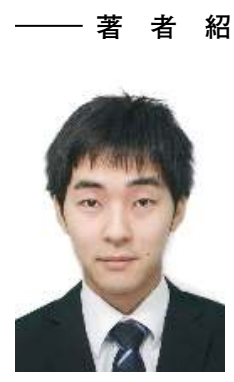

加藤 優太 [非会員]

2019 年，中京大学工学部機械システム工学科 卒業. 2021 年, 中京大学工学研究科機械シス テム工学専攻修了. 機械学習の研究に従事. 強化学習問題に興味を持つ. IEEE 会員.

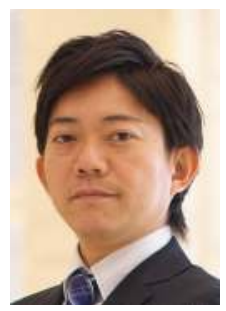

加納 政管 [正会員]

2004 年名古屋工業大学大学院工学研究科博 士後期課程電気情報工学専攻修了. 同年中京 大学講師, 2010 年准教授, 2015 年教授, 現 在に至る. 博士 (工学). 感性・知能ロボティ クス, インタラクションの研究に従事. 2006 年日本感性工学会技術賞, 2010 年日本知能情 報ファジィ学会論文賞, 2016 年日本知能情報 ファジィ学会著述賞. IEEE Senior 会員, 日本 ロボット学会, 人工知能学会, 日本感性工学 会, 情報処理学会, 電子情報通信学会各会員.

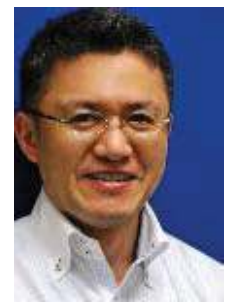

中村㓮士 [正会員]

1998 年名古屋工業大学大学院博士後期課程修 了. 1998 年同大学助手. 2003 年同大学大学 院工学研究科助教授. 2007 年准教授. 2021 年中部大学工学部教授。現在に至る。CG, $\mathrm{CV}, \mathrm{HRI}$, ソフトコンピューティング等に関 する研究に従事. ACM, IEEE，電子情報通信 学会, 人工知能学会各会員. 博士 (工学).

\section{Reward Function Considering Ambiguity Using Inverse Reinforcement Learning and Fuzzy Reasoning}

by

Yuta KATO, Masayoshi KANOH, and Tsuyoshi NAKAMURA

\section{Abstract:}

A reward function estimated with inverse reinforcement learning has been used to determine a method for controlling a robot. The number of state transitions that can be observed using the action sequence given to inverse reinforcement learning decreases drastically as the complexity of the planning problem increases. Although a reward function can be designed even from partial state transition information, ambiguity in the obtained reward function exists. A reward function that can tolerate ambiguity is required when learning with a reward function that includes ambiguity. In this paper, we propose a method for quantifying the ambiguity of the reward function, which is designed with inverse reinforcement learning using fuzzy reasoning. Experimental results was suggested that proposed method can learn the action sequence while considering the degree of risk and safety.

Keywords: inverse reinforcement learning, fuzzy reasoning, reward function

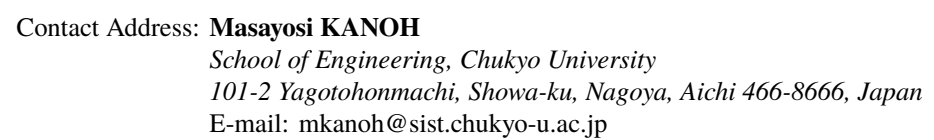

